\title{
ANALISIS PENGARUH PROFITABILITAS DAN LIKUIDITAS TERHADAP OPINI AUDIT GOING CONCERN
}

\author{
Abdurrachman', Rizky Amalia ${ }^{2}$, Bryan Givan $^{3}$ \\ Universitas Bina Sarana Informatika \\ Jakarta, Indonesia \\ Abdurrachman.bdr@bsi.ac.id, Rizky.ram@bsi.ac.id, Bryan.bgv@bsi.ac.id
}

\begin{abstract}
Companies that receive a going concern audit opinion show events and conditions that would cause the auditor to doubt about the going concern of the company. This opinion can be used as an initial signal for users of financial statements to avoid mistakes when making a decision. Regarding the factors that influence going-concern audit opinion, many previous studies have been carried out. However, it has inconsistencies in the results of the study. Thus, the research aims to carry out retesting related "factors that influence going concern audit opinion". The variables tested include Profitability and Liquidity. The research sample uses manufactur companies in the consumer goods industry which were listed on the Indonesian Stock Exchange for the period 2018-2019. The sampling technique was purposive sampling, which obtained 102 companies' data that matched the criteria. Logistic regression analysis was used to test the hypothesis of this study. Hypothesis testing results that partially the profitability and liquidity variables have no effect on goingconcern audit opinion.
\end{abstract}

Keyword: Profitability, Likuidity, Going Concern Audit Opinion

\section{PENDAHULUAN}

Going Concern atau umum dinamakan juga dengan keberlangsungan hidup entitas senantiasa dikaitkan dengan kapabilitas pengelolaan manajemen perusahaan, menjaga aktivitas usaha dalam periode waktu lama, serta dalam jangka waktu pendek tidak akan menutup usahanya. Entitas bisnis sendiri pada perkembangannya sudah banyak dicampuri dengan berbagai kasus hukum seperti manipulasai akuntansi. Investor atau pemakai laporan keuangan lainnya akan lebih mudah mempercayai data perusahaan bila dalam laporannya menunjukkan kondisi dan kinerja perusahaan yang sebenarnya.

Pemberian opini audit going concern termasuk tugas yang sulit sebab ini akan menyangkut reputasi auditor. Kekeliruan dalam pemberian opini bisa berdampak signifikan untuk pemakai laporan keuangannya. Opini audit going concern yang dikeluarkan berlawanan dengan harapan perusahaan bisa mengakibatkan nilai jual saham mengalami kemunduran, di mana ini akan menjadikan perusahaan kesulitan dalam memperoleh dana dari investor. Bukan hanya hal tersebut, upaya meningkatkan modal pinjaman juga akan sulit sehingga 
akan memicu kreditur, investor, karyawan dan pelanggan tidak percaya dengan manajemen perusahaan. Publik yang hilang kepercayaan pada manajemen perusahaan ini tentunya juga berdampak signifikan pada going concern perusahaan ke depannya.

Lenard dkk., (2000) memaparkan, going concern yaitu sebuah asumsi dimana perusahaan bisa menjaga keberlangsungan hidupnya (going concern) yang tentunya akan berpengaruh langsung terhadap laporan keuangan. Penyiapan laporan keuangan diasumsikan bila perusahaan tidak going concern. Secara dasarnya going concern melalui penyampaian laporan keuangan akan mengindikasikan bahwasanya perusahaan dapat mempertahankan dirinya dengan waktu yang lebih lama.

\section{Standar Audit ("SA") 570} menyatakan tanggung jawab auditor adalah untuk memperoleh bukti audit yang cukup dan tepat tentang ketepatan penggunaan asumsi kelangsungan usaha oleh manajemen dalam penyusunan dan penyajian laporan keuangan, dan untuk menyimpulkan apakah terdapat suatu ketidakpastian material tentang kemampuan entitas untuk mempertahankan kelangsungan usahanya. Pernyataan Standar Auditing (PSA) 29 paragraf 11 huruf d (IAI:SA Seksi 508,
Paragraf 11) menyatakan kesangsian akan kapabilitas suatu usaha dalam menjaga kelangsungan hidupnya (going concern) merupakan kondisi yang mengharuskan agar auditor menambah bahasa penjelas atau paragraf penjelas dalam laporan auditnya, walaupun hal ini tidak memberi pengaruh pada unqualified opinion (pendapat wajar tanpa pengecualian) yang auditor nyatakan.

Profitabilitas yakni instrumen yang dimanfaatkan sebagai pengukur kondisi keuangan perusahaan. Sementara untuk profitabilitas sendiri diartikan sebagai kemampuan perusahaan mendapatkan keuntungan dalam kaitannya dengan modal sendiri, total aktiva, maupun penjualan (Sartono, 1998). Analisa profitabilitas dapat diproksikan mengggunakan rasio ROA (Return On Asset) dengan cara melakukan pembagian rugi/laba bersih dengan jumlah keseluruhan aset. Rasio ini dimanfaatkan guna melihat manajerial efisiensi secara keseluruhan dan kemampuan manajemen perusahaan dalam mendapatkan keuntungan. ROA yang nilainya bertambah tinggi, maka diasumsikan pengelolaan aktiva perusahaan semakin efektif. Sehingga, bertambah besarnya rasio profitabilitas memperlihatkan semakin baiknya kinerja perusahaan, dengan demikian persusahaan dengan laba 
tinggi auditor tidak akan memberi opini audit going concern.

Penelitian Ariesetiawan dan Rahayu (2015) dan Indriastuti (2016) menghasilkan bahwa rasio profitabilitas memberi pengaruh negatif signifikan dalam penerbitan opini audit going concern, akan tetapi Suksesi dan Lastanti (2016) dan Yuliani dan Erawati (2017) dalam penelitiannya mendapatkan hasil yaitu rasio profitabilitas tidak memberi pengaruh signifikan terhadap penerbitan opini audit going concern.

Likuiditas merupakan kapabilitas perusahaan dalam menginterpretasikan dan menganalisa posisi keuangan jangka pendeknya atau kemampuan dalam menyelesaikan kewajiban jangka pendeknya (Munawir, 2002). Pengukuran taraf likuiditas perusahaan bisa dengan current ratio. Perhitungannya yakni dengan membagikan aktiva lancar dengan hutang lancar. Rasio tersebut memperlihatkan seberapa jauh hutang lancar dengan aktiva lancar mampu menutup segala kewajiban lancarnya. Bertambah besarnya selisih aktiva lancar dengan hutang lancar tersebut akan menjadikan bertambah tingginya kemampuan perusahaan menutup kewajiban jangka pendek. Bila perusahaan gagal memenuhi klaim kreditor jangka pendeknya, maka akan bisa berpengaruh pada kredibilitasnya serta bisa dinilai sebagai sebuah pertanda bahwa perusahaan tengah mengalami permasalahan yang bisa menghambat keberlangsungan usahanya.

Penelitian Ariesetiawan dan Rahayu (2015) dan Indriastuti (2016) memanfaatkan variabel current ratio dalam penelitiannya serta hasilnya yaitu current ratio memberi pengaruh signifikan pada keputusan opini audit going concern. Akan tetapi, Suksesi dan Lastanti (2016) dan Yuliani dan Erawati (2017) menjelaskan, rasio likuditas dengan proksi current ratio tidak memberi pengaruh signifikan pada penerbitan opini audit going concern.

Dikarenakan adanya perbedaan hasil dari penelitian sebelumnya maka dilakukan penelitian kembali menggunakan data laporan keuangan audited perusahaan manufaktur yang terdaftar BEI sektor industri barang konsumsi periode tahun 2018-2019, dan dengan kerangka pemikiran sebagai berikut:

Gambar 1. Kerangka Pemikiran

Variabel Independen Variabel Dependen

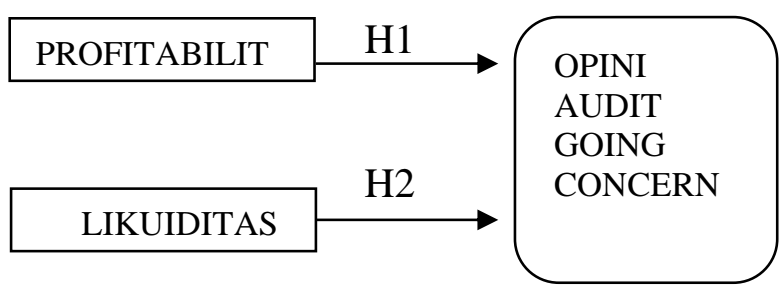

(Sumber: Diolah oleh Penulis) 


\section{METODE PENELITIAN}

Penelitian ini memanfaatkan data sekunder dari www.idx.co.id dengan populasinya yaitu perusahaan manufaktur sektor Industri Barang Konsumsi yang terdaftar di Bursa Efek Indonesia periode 2018-2019 sebanyak 54 perusahaan. Pengambilan sampel dilakukan dengan metode purposive sampling dan melakukan uji regresi logistik pada sampel.

\section{HASIL DAN PEMBAHASAN}

Hasil Penelitian sebagai berikut:

\section{a. Analisis Statistik Deskriptif}

Statistik deskriptif dari teknik purposive sampling menghasilkan 102 data observasi dimana ini dapatkan dari sampel (54 perusahaan) dengan periode penelitian (2 tahun).

\section{Tabel 1. Statistik Deskriptif}

\begin{tabular}{|c|c|c|c|c|c|}
\hline & $\mathrm{N}$ & Min & Max & Mean & $\begin{array}{l}\text { Std. } \\
\text { Deviasi }\end{array}$ \\
\hline Profitablitas & 102 & -1.37 & 0.92 & 0.0717 & 0.20245 \\
\hline Likuiditas & 102 & 0.00 & 12.63 & 2.6169 & 2.30471 \\
\hline $\begin{array}{l}\text { Opini Audit } \\
\text { Going } \\
\text { Concern }\end{array}$ & 102 & 0 & 1 & 0.02 & 0.019 \\
\hline $\begin{array}{l}\text { Valid } \\
\text { (listwise) }\end{array}$ & 102 & & & & \\
\hline
\end{tabular}

(Sumber: Data Olahan SPSS, 2021)

\section{b. Pengujian Kelayakan Model}

\section{Regresi}

Nilai signifikansi dari pengujian kelayakan ini melalui uji Hosmer and Lemeshow Goodness of Fit Test yakni senilai 1,000 dimana ini melebihi 0,05. Maknanya, model regresi penelitian ini bisa dimanfaatkan dalam analisis berikutnya, sebab antara data asli dan model regresi terdapat kecocokan.

\section{c. Menilai Keseluruhan Model}

\section{(Overall Model Fit)}

Overall model fit pada -2LL Block Number $=0$ dimana -2 LL Block Number $=1$ menurun yakni $19.688-0,000=$ 19,688. Likelihood yang menurun tersebut memperlihatkan model dalam penelitian fit akan data atau model regresinya dinilai baik.

\section{d. Koefisien Determinasi (Nagelkerke}

\section{R Square)}

Hasil yang didapat yakni kombinasi kedua variabel bebas, (profitabilitas dan likuiditas) dalam menjelaskan varian opini audit going concern sebagai variabel tergantungnya adalah sejumlah $100 \%$.

\section{e. Pengujian Koefisien Regresi dan}

\section{Hipotesis}

Tabel 2. Hasil Pengujian Koefisien Regresi

\begin{tabular}{llllll}
\hline & B & S.E. & $\begin{array}{l}\text { Wal } \\
\text { d }\end{array}$ & df & Sig \\
\hline Profitabilitas & $\mathbf{- 4 1 7 . 0 8 8}$ & 14586.991 & .001 & 1 & $\mathbf{. 9 7 7}$ \\
Likuiditas & $\mathbf{- 4 9 . 1 6 7}$ & 1670.427 & .001 & 1 & $\mathbf{. 9 7 7}$ \\
Constant & $\mathbf{- 8 . 6 7 9}$ & 539.846 & .001 & 1 & $\mathbf{. 9 7 7}$ \\
\hline (Sumber: Data Olahan & SPSS 2021$)$ & & &
\end{tabular}

(Sumber: Data Olahan SPSS, 2021)

Hasil analisis model regresi yang didapat yaitu:

$\operatorname{Ln}=\alpha+\beta 1$ (profitabilitas) $+\beta 2$

(likuiditas)

Ln $=-8.679-417.088$ (profitabilitas) 49.167 (likuiditas)

Analisis pengujian hipotesis dapat dijelaskan di bawah ini: 


\section{Profitabilitas}

H1: Pengaruh Profitabilitas terhadap Opini Audit Going Concern.

Ha1: Profitabilitas berpengaruh terhadap Opini Audit Going Concern.

Ho1: Profitabilitas tidak berpengaruh terhadap Opini Audit Going Concern.

Keputusan: Ho diterima karena sig > 0,05 yaitu 0,977 .

Hipotesis pertama yaitu "profitabilitas memberi pengaruh pada opini audit going concern". Hasilnya, koefisien regresi variabel profitabilitas bernilai negatif yakni -417.088 dengan signifikansinya senilai $0,977>0,05$. Sehingga, kesimpulannya adalah $\mathrm{H} 1$ ditolak atau variabel profitabilitas secara parsial tidak memberi pengaruh pada opini audit going concern.

\section{Likuiditas}

H2: Pengaruh Likuiditas terhadap Opini Audit Going Concern.

Ha2: Likuiditas berpengaruh terhadap Opini Audit Going Concern.

Ho2: Likuiditas tidak berpengaruh terhadap Opini Audit Going Concern.

Keputusan: Ho diterima karena sig > 0,05 yaitu 0,977 .

Hipotesis kedua yaitu "likuiditas berpengaruh pada opini audit going concern". Hasilnya didapatkan koefisien regresi variabel likuiditas bernilai negatif yaitu -49.167 dengan signifikansinya senilai $\quad 0,168 \quad>0,05 . \quad$ Sehingga kesimpulannya, $\mathrm{H} 2$ ditolak atau variabel likuiditas secara parsial tidak memberi pengaruh pada audit going concern.

Pembahasan Hasil Penelitian sebagai berikut:

\section{a. Profitabilitas Tidak Berpengaruh Terhadap Opini Audit Going Concern}

Hasil penelitian ini menolak hipotesis pertama. Rasio keuangan ROA (Return On Asset) dimanfaatkan guna melihat pengaruh Profitabilitas terhadap opini audit going concern. Bertambah besarnya nilai ROA perusahaan, maka kemampuannya untuk menghasilkan laba juga akan bertambah besar. Akan tetapi, Profitabilitas tidak menjadi satu-satunya ukuran yang menjadi keputusan auditor ketika memberi Opini Audit Going Concern, sebab auditor juga harus mengukur kapabilitas untuk pelunasan seluruh kewajiban pada suatu perusahaan. Hasil penilitian ini juga sejalan dengan penilitan dari Suksesi dan Lastanti (2016) dan Yuliani dan Erawati (2017) dengan hasil yaitu rasio profitabilitas tidak memberi pengaruh signifikan pada penerbitan opini audit going concern. 


\section{b. Likuiditas Tidak Berpengaruh Terhadap Opini Audit Going \\ Concern}

Hasil penelitian ini menolak hipotesis kedua. Rasio keuangan Current Ratio (CR) dimanfaatkan untuk melihat pengaruh likuiditas terhadap opini audit going concern. Bertambah besarnya nilai rasio CR perusahaan, maka bertambah besar juga kemampuannya untuk membayar kewajiban jangka pendek.

Artinya, auditor ketika memberi opini audit going concern bukan sebatas mengacu kepada pertimbangan kapabilitas perusahaan guna memenuhi kewajiban jangka pendeknya saja, namun juga berfokus terhadap kapabilitas perusahaan dalam melunasi seluruh kewajiban yang dimilikinya. Uraian hasil penelitian ini selaras akan penelitian dari Suksesi dan Lastanti (2016) dan Yuliani dan Erawati (2017) dimana hasilnya yaitu likuiditas tidak memberi pengaruh pada pemberian opini audit going concern.

\section{SIMPULAN DAN SARAN}

Kesimpulan hasil penelitian yang bisa diuraikan yaitu:

Profitabilitas tidak memberi pengaruh signifikan terhadap opini audit going concern. Uraian hasil ini ditunjang oleh penelitian dari Suksesi dan Lastanti (2016) dan Yuliani dan Erawati (2017) dimana hasilnya menunjukkan profitabilitas tidak memberi pengaruh signifikan pada opini audit going concern.

Likuiditas tidak memberi pengaruh signifikan pada opini audit going concern. Uraian hasil penelitian ini selaras akan penelitian dari Suksesi dan Lastanti (2016) dan Yuliani dan Erawati (2017) dimana hasilnya yaitu Likuiditas tidak memberi pengaruh signifikan pada opini audit going concern.

Saran penelitian yang bisa diuraikan di antaranya yaitu:

(1) Bagi akademisi, untuk penelitan berikutnya diharapkan mempergunakan objek penelitian pada perusahaan dengan jenis industri yang lain dan menggunakan variasi variabel lain yang menjadi faktor pencegah dan penyebab diberikan opini audit going concern. Diantaranya dengan variabel leverage, good corporate governance, debt default, dan pergantian auditor sebagai variabel independen.

(2) Bagi praktisi, sebaiknya dalam pengambilan keputusan manajemen dapat memperhatikan rasio rasio keuangan secara komprehensif, sehingga keputusan yang diambil dapat mencegah terjadinya pemberian opini audit going concern.

(3) Bagi Investor, sebaiknya melakukan analisa secara komprehensif terhadap laporan keuangan untuk mengetahui 
apakah keberlangsungan perusahaan bisa bertahan dalam periode yang lama sebelum melakukan investasi.

\section{DAFTAR PUSTAKA}

\section{BUKU}

Belkaoui, A. R. (1997). Accounting Theory, 4 th Ed. Jakarta: Salemba Empat.

Board, A. S. (1988). Statement on Auditing Standards No.59: The Auditors' Consideration of an Entity's Ability to Continue as a Going Concern. New York: AICPA.

Ikatan Akuntansi Indonesia. (2001). Standar Profesional Akuntan Publik. Jakarta: Salemba Empat.

Institut Akuntan Publik Indonesia. (2012). Standar Audit ("SA") 570 (pp.1-16). pp. 1-16. Institut Akuntan Publik Indonesia.

Munawir. (2002). Akuntansi Keuangan dan Manajemen. Edisi Revisi. Penerbit BPFE: Yogyakarta.

Sartono. (1998). Manajemen Keuangan Teori dan Aplikasi. Yogyakarta: BPFE.

\section{JURNAL}

Ariesetiawan, Aldy., dan Rahayu, Sri (2015). Pengaruh Profitabilitas, Likuiditas dan Pertumbuhan Perusahaan Terhadap Penerimaan Opini Audit Going Concern. EProceeding of Manajemen, 402-409.

Indriastuti, Maya (2016). Pengaruh Profitabilitas dan Likuiditas Terhadap Penerimaan Opini Audit Going Concern. Fokus Ekonomi: Jurnal Ilmiah Ekonomi, Vol. 11 No.2: 37-50.

Lenard MJ, Alam P, B. D. (2000). An analysis of fuzzy clustering and $a$ hybrid model for the auditor's going concern assessment. Decision Sciences 31(4): 861-884.
Lie, Christian, dkk. (2016). Pengaruh Likuiditas, Solvabilitas, Profitabilitas, dan Rencana Manajemen terhadap Opini Audit Going Concern (Studi Empiris pada Perusahaan Manufaktur di BEI). Berkala Akuntansi dan Keuangan Indonesia, Vol. 1, No. 2, Hlm 84-105.

Masyitoh, O. C. and D. A. (2010). The Analysis of Determinants of Going concern Audit Report. Journal of Modern Accounting and Auditing. Vol. 6, No.4: 26-37.

Rahayu, P. (2007). Assessing Going concern Opinion: A Study Based on Financial and Non-Financial Information. Makalah Disampaikan Dalam Simposium Nasional Akuntansi X, Makassar: 26-28 Juli.

Suksesi, G. W., Lastanti, H. S. (2016). Pengaruh Opini Audit Tahun Sebelumnya, Reputasi Auditor, Ukuran Perusahaan, Profitabilitas, Likuiditas, dan Solvabilitas Terhadap Pemberian Opini Audit Going Concern. Prosiding Seminar Nasional Cendekiawan (pp. 1-10).

Yuliani, N. M. A., Erawati, N. M. A. (2017). Pengaruh Financial Distress, Profitabilitas, Leverage dan Likuiditas Pada Opini Audit Going Concern. E-Jurnal Akuntansi Universitas Udayana. Vol 19, No. 2: 1490-1520.

\section{INTERNET}

https://www.idx.co.id/perusahaantercatat/laporan-keuangan-dan-tahunan 
PROGRESS

Jurnal Pendidikan, Akuntansi dan Keuangan

Universitas Banten Jaya
Vol 4 No. 2, Agustus 2021

E-ISSN 2622-7037 |P-ISSN 2623-0763 